\title{
K historii literatury na Karvinsku do roku 1945
}

\author{
Libor Martinek (Opava - Wrocław)
}

\begin{abstract}
Abstrakt
Problematika regionální literatury Karvinska tvoři jednu z důležitých složek regionálního vědomí obyvatel dané oblasti a souvisí ve větší či menší mir̃e s kulturními aspiracemi jeho obyvatel a tvưrců, kteři je reprezentují. (Samotnou Karvinou v našem článku míníme z historických a administrativně-správních důvodů tzv. velkou Karvinou, která se skládá z Karviné, Fryštátu, Karviné-Ráje, Starého Města, Darkova a Louk. Pojmem Karvinsko myslíme bývalý politický okres.) Literárněvědný výzkum v regionu nemusí být ústupem od celostních hledisek národní literatury, ani z nároků na zkoumané hodnoty. Specifický územní a typologický výzkum nám umožnil, abychom se detailněji zaměřili jak k samotnému vývoji českého a polského písemnictví na Karvinsku, tak ke komparativnímu pohledu na stýkání se české a polské literatury (zdejší německou literaturu v našem článku nereflektujeme).
\end{abstract}

\section{Klíčová slova}

regionální literatura; regionálního vědomí; literárněvědný výzkum; územní a typologický výzkum

\section{Abstract \\ On the History of Literature in the Region of Karviná up to 1945}

The issue of regional literature of Karvinás region is one of the important components of the regional consciousness of the inhabitants of the area and is connected to the cultural aspirations of its inhabitants and the creators representing them to a greater or lesser extent. (Karvina, in our contribution, we mean for the historical and administrative-administrative reasons the so-called great Karviná, which consists of Karviná, Fryštát, Karviná-Ráj, Staré Město, Darkov and Louky. The term Karviná's region we mean the former political district.) Literary research in the region may not be a departure from the holistic aspects of national literature, nor from claims to the values surveyed. Specific territorial and typological research has allowed us to focus more closely on the development of Czech and Polish literature in Karviná's region, as well as on a comparative view of Czech and Polish literature (German literature in this paper does not reflect our contribution).

\section{Key words}

regional literature; regional consciousness; literary research; territorial and typological research 
Problematika regionální literatury Karvinska, ${ }^{1}$ která tvoří jednu z důležitých složek regionálního vědomí obyvatel dané oblasti a souvisí ve větší či menší míře s kulturními aspiracemi jeho obyvatel a tvůrců, kteří je reprezentují, přináší závažnější metodologické problémy. Jakmile si totiž vymezíme literární tvorbu topograficky, geograficky a lokálně, dostáváme se bud' na půdu vlastivědy, nebo literárního místopisu či zeměpisu (kde je problematika lokální slovesnosti zkoumána ponejvíce, ne-li výhradně, s důrazem na biograficko-bibliografická fakta a má spíše kulturněhistorický význam), případně literární sociologie. Pokud přistoupíme k interpretaci literárních děl, začíná nás zajímat estetická funkce literárního díla, spolu s tím i jeho sociálně-psychologické aspekty.

Regionální literárněvědný výzkum nemusí být ústupem od celostních hledisek národní literatury, ani z nároků na zkoumané hodnoty. Specifický územní a typologický výzkum nám umožnil, abychom se detailněji zaměřili jak samotnému vývoji českého a polského písemnictví v regionu Karvinska, tak komparativnímu pohledu na stýkání se české a polské literatury (zdejší německou literaturu v našem příspěvku nereflektujeme). Zároveň jsme považovali za důležité poukázat i na skutečnost vzniku literárních děl autorů, kteří nejsou rodáky z Karvinska, ale odjinud, a kteří do regionu přišli převážně za prací, avšak brali si z něj ve své literární tvorbě inspiraci. Zásadním kritériem pro podrobnější pojednání o dílech vybraných autorů pak byl význam jejich literárního díla; máme přitom na mysli beletrii, tedy texty s převahou estetické funkce, nikoli lokální písemnictví v jeho celku, jehož výzkum patří spíše do vlastivědy, literárního místopisu, popřípadě do sféry kulturně-antropologického bádání.

Starší krásná literatura na Karvinsku není zastoupena památkami výjimečné hodnoty, ${ }^{2}$ ostatně Karviná nebyla významným kulturním centrem v regionu, ani Fryštát, jenž je dnes centrem města, který byl původně samostatným městem a prvním nositelem městského práva, nyní tvoří jednu z devíti městských částí Karviné. ${ }^{3}$ Náboženská literatura, zábavná a populární četba atp. sem byly převážně importovány odjinud. Situace se radikálně mění v 2. polovině 18 . století, kdy nález ložisek černého uhlí v Karviné přinesl zásadní obrat v hospodářském rozvoji celého regionu. Dosud méně významná vedlejší obec Karviná tak má již na počátku 20. století zásadní ekonomický význam pro celou Rakousko-Uherskou monarchii. Rozvoj v ekonomické oblasti přinesl potřebu větší informovanosti, do regionu přicházejí v masivním počtu pracovní síly z jiných oblastí monarchie (významný byl proud polského obyvatelstva z Haliče), vznikají tiskárny, vydá-

1 Karvinskem se všeobecně míní bývalý okres Karviná, avšak tady je třeba si uvědomit, že v jeho hranicích se od roku 1960 ocitá politický okres Český Těšín; přitom oblast Karvinska se od bývalého okresu Český Těšín v mnohém kulturně i etnograficky odlišuje v důsledku industrializace zejména ostravsko-karvinského revíru, zatímco východní oblast českého Těšínska zůstává (s výjimkou Třinecka) převážně zemědělská a etnicky stabilnější. Z tohoto důvodu v našem článku neuvádíme autory patřící svou tvorbou do oblasti Českého Těšína a jeho okolí. (Bývalý okres Karviná se skládal z pěti obvodů obcí s rozšířenou působností, které jsou shodné s obvody obcí s pověřeným úřadem: Bohumín, Český Těšín, Haviřrov, Karviná, Orlová.)

2 Archivní památky typu pergamenových listin, kopiářo̊ a městských knih, do beletrie, tedy ani do diskursu našeho článku, nezařazujeme. (Nejstarší archiválií, dochovanou ve Státním okresním archivu Karviná, je biskupská pergamenová listina z 18. 2. 1377, která potvrzuje nadaci těšínského knížete Přemka farnímu kostelu ve Fryštátě.)

3 Správní základ dnešního města byl položen roku 1948, kdy se sloučily obce Fryštát, Karviná, Darkov, Ráj a Staré Město v jeden celek pojmenovaný Karviná. 
vají se noviny a jiné periodické publikace, vydávají se knihy. Ještě před první světovou válkou zaujme širokou českou kulturní veřejnost vystoupení Petra Bezruče, jenž ve svých Slezských pisnich zobrazuje úděl proletariátu, ale i mizerně placené české inteligence (učitelů) v regionu (báseň Kantor Halfar), v kontrastu s postavami zdejších velkopodnikatelů, uhlobaronů, velkostatkářů („markýz Gero“5 je kryptonymem arcivévody Bedřicha Habsburského, vlastníka řady průmyslových podniků zejména na Těšínském Slezsku a Ostrav$\left.\mathrm{sku}^{6}\right)$, německých, rakouské vládě loajálních úředníků jako př́íině germanizace. „Tak je ti protivný té mluvy zvuk, / horši nad ní neni žádné? / Lem tvého roucha sto pozvedá ruk, / sto rabů do noh ti padne. / Kněze, jenž naší by modlil se řeči, / rektora, jenž by ji učil v tvém zboži, / vyženeš ze vsi: ví Bůh, že jsi větš̌ / v zášti než plamenný nepř́tel boži, / markýzi Géro! // Až tam za / hranicí najimášs vrahy, / kypici pýchou a hořici žlučì. / Sám řekneš: Mně je ten národ tak drahý / jak jiný: jméno a rod za to ruči. / Ve jménu božim kdys křižáci koly / tak jednou zem naši zbarvili krví. / V rachotu bubnů, na červeném poli, / dá Bůh, že ti uzdu kdys padnu já prvý, / markýzi Géro! // Tak se ti libi ti za řekou muži, / tak blaze v jich středu, markýzi, je ti? / Znaji jen věnce plést $z$ trnových růží, / znaji jen můj národ ubijeti. / Pro nás švih bičem a konopnou šnuru, / knižecí úsměv jen pro ně, jen pro ně: / v požáru, v dýmu až zdvihnem se vzhưru, / dá Bůh, že tě jednou strhneme s koně, / markýzi Géro!"“7

Naopak ve prospěch polského etnika na Karvinsku se angažuje Franciszek Friedel (1870-1947), jenž sestavil Zbiór pieśni ludu ślaskiego (Fryštát, 1896). Stoupenci jeho politiky bývali nazýváni „fryštátskými radikály“ nebo „friedlovci“. V roku 1898 založil osvětovou společnost Jedność, která se mj. zabývala vydavatelskou činností. Z jeho iniciativy se tato organizace přetvořila na místní skupinu Macierzy Szkolnej dla Śląska Cieszyńskiego (vznikla v Těšíně v roku 1886). Matice školská pro Těšínské Slezsko byla aktivní také edičně a napomáhala rozvíjet polský kulturní i literární život. Její snahy se týkaly boje za polství (polské školství, kulturu, osvětu apod.) rovněž v ostravsko-karvinském revíru také $\mathrm{s}$ ohledem na př́liv pracovních sil z Haliče, zejména z Malopolska. ${ }^{8}$ Možnost mladých dělníků z Karvinska dále se vzdělávat v Polsku využil horník Gustaw Morcinek.

4 Tato problematika spadá do dějin knihtisku a žurnalistiky, proto se jí zde podrobněji nezabýváme.

5 Podle markraběte Východní marky z 10. století Gera (909-965) vyvraždujícího slovanské polabské kmeny.

6 Friedrich Maria Albrecht Wilhelm Karl von Österreich-Teschen, tedy Bedřich Rakousko-Těšínský, arcivévoda rakouský (1856-1936) je v současné historiografii hodnocen příznivěji, nebot? se jeví jako hospodářský reformátor, podporovatel nových výrobních technologií, vzdělanosti a kultury, „ekolog“, jenž v bukových pralesích na Mionší a v Salajce založil jednu z nejstarších přírodních rezervací, lidumil, který zavedl fond pro vdovy a sirotky zaměstnanců. Na druhou stranu omezoval sociální výdaje, aby víc vydělal. Zkrátka choval se jako správný dnešní podnikový manažer.

7 BEZRUČ, Petr: Slezské písně. Ed. Drahomír Šajtar. Praha: SPN, 1958, s. 126-127.

8 První lidová polská škola byla založena v roku 1904 v tehdejší Polské, dnes Slezské Ostravě, následovala lidová škola Doubravě, o něco dříve, roku 1909, bylo založeno polské gymnázium v Orlové, v letech 1909-1914 vzniklo osm polských škol zaměřených na výuku řemeslníků, dnes bychom je nazvali učilišti, které organizovaly i kurzy psaní a čtení pro analfabety z Haliče. Jednou ze základních sfér působnosti Matice bylo propagování čtenářství polských knih a tisku, vyvíjela i osvětovou činnost na téma polské historie a kultury, hygieny nebo př́rodních věd, rozvíjel se amatérský divadelní a sborový pěvecký ruch. Pod názvem Macierz Szkolna w Czechosłowacji vyvíjela Matice svou činnost na našem území i po rozdělení Těšínského Slezska v roku 1920 na část československou a polskou; jejím předsedou byl polský lékař, národní a sociální aktivista dr. Wacław Olszak (1868-1939) z Karviné, jejímž starostou byl v letech 1929-1936 


\section{Meziválečné období v literatuře Karvinska}

Spisovatelé z Těšínska dlouhodobě tvořili především z mimoestetických důvodů, z národních a společenských pohnutek. Jejich tvorba byla reakcí na společenskou zakázku a byla určena zejména lidovému příjemci. Takováto orientace literární tvorby přetrvává i po roku 1920, tedy po období vzniku „dvojího“ Těšínska. Na českém Těšínsku měla splňovat očekávání čtenářské obce a být oporou ve chvílích ohrožení národních zájmů místních Poláků. Tento požadavek byl na literaturu vznikající na Těšínsku kladen ještě po druhé světové válce.

Na českém Těšínsku silně zastoupená lidová tvorba se bude nadále rozvíjet ve dvou proudech - dělnickém a selském. První směr ohlašovala tvorba hornického tesaře z Horní Suché a knihovníka Franciszka Siwka (1858-1933); z hlediska publikovaných děl by ještě patřil do literatury před rokem 1920, ale z pohledu imanentního vývoje již spadá do proudu dělnických autorů. Z jeho příspěvků uveřejněných na stránkách časopisů připomeňme Pamięci zabitych braci-górników (Památce zabitých bratrů horníků; 1895), Na grób Józefa Szymana (Na hrob J. Szymana; 1896), Na powitanie „Gtosu Ludu Ślaskiego “ (Na uvítanou Hlasu slezského lidu; 1897) a Pieśn cieślarzy (Píseň tesařů; 1897); ukázky z tvorby F. Siwka uveřejnila Janina Kucianka v antologii Ślascy pisarze ludowi, 1800-1914 (Slezští lidoví spisovatelé, 1800-1914; Wrocław, 1968). Tento proud však narazil bud' na obtíže ze strany ideových protivníků, nebo jeho představitelé byli odsouzeni k anonymitě, případně se vázal s významnějším literárním směrem té doby, tedy se selským proudem písemnictví.

Ve Stonavě působil horník Alojzy Bonczek (1865-1937), aktivní v hornickém sdružení Prokop, po určitou dobu redaktor jeho časopisu Górnik (Horník). Po první světové válce působil v Národní radě Těšínského knížectví a na polském konzulátu v Ostravě. Zemřel ve Stonavě. Kromě politicko-sociálních a popularizačních brožur vydal Pamiętnik, zawierajacy przygody z życia, mtodości, rozwój $i$ wspótprace w zakresie publiczno-spotecznym na Ślasku Cieszyńskim w czasie 1865-1920 (Vzpomínky obsahující příhody ze života, mládí, rozvoje a spolupráce ve společensko-sociální oblasti na Těšínském Slezsku v letech 1865-1920; Fryštát, 1930).

Karvinský rodák, Emanuel Grim (1883-1950), povoláním katolický kněz (studoval v Krakově a ve Vidnavě, po roku 1917 se usadil v Istebné), byl autorem mj. dramatu Obrona Karwiny (Dla Ciebie, Polsko) (Obrana Karviné /Pro tebe, Polsko/), které vzniklo v polovině třicátých let a je věnováno událostem roku 1919, kdy na Karvinsku přešla vláda pod Československou republiku s pomocí československého vojska.

V druhém, selském literárním směru, rozvíjeném zejména ve východní části Těšínského Slezska získal na významu učitel Walenty Krząszcz (1886-1959) jako velmi plodný autor povídek, pověstí a propagátor venkovského lidového umění. Také folkloristické

(od roku 1931 byl předsedou Matice Piotr Feliks, 1888-1941, ředitel Polského gymnázia J. Słowackého v Orlové). Po válce byla činnost Matice školské v Československu obnovena, po únoru 1948 zčásti přešla organizačně a majetkově pod Polský svaz kulturně-osvětový (Polski Związek Kulturalno-oświatowy; zkr. PZKO) a zanikla, problematikou polského školství se výhradně zabýval KNV v Ostravě. Matice pak byla reaktivována po politických změnách v roku 1989. 
inspirace postupně nabývaly výraznější umělecké podoby. Rodák z Jablunkova, katolický kněz Oskar Zawisza (1878-1933) působil od roku 1911 v Těrlicku. Kromě řady historických a folkloristických prací vydal také Śpiewnik górniczy (Hornický zpěvník, 1922), napsal symfonickou báseň Znad brzegów Olzy (Od břehů Olzy) a symfonii $Z$ niwy ślaskiej (Ze slezské nivy), operu Czarna Księżna, pani z Kościelca (Černá kněžna, paní z Kostelce) a další scénická díla, např. Jasetka (Jesličky, 1922), Święta Barbara (Svatá Barbora, 1922), Czarne diamenty (Černé diamanty, 1929) nebo Dożynki (Dožínky).

Polská inteligence reagovala dlouhodobě odmítavě, co se prózy a publicistiky týče, na prózy Františka Sokola Tůmy a Anny Marie Tilschové, na publicistiku Joži Vochaly9 . Patřily by sem i některé práce Gustawa Morcinka, např. článek Wspomienie z przewrotu w listopadzie 1918 r. (Vzpomínka z převratu v r. 1918), uveřejněný v roku 1920 v Dzienniku Cieszyńském (Těšínském deníku), román na pokračování z doby polsko-českých bojů o Těšínské Slezsko W obronie progu (V obraně prahu), otiskovaný v roku 1926 na stránkách Głosu Ludu Śląskiego (Hlasu slezského lidu), který nebyl dokončen, ale stal se základem jeho později knižně vydaného románu Wyrąbany chodnik 1-2 (Proražená chodba, 1931-1932), a novela Maszerować! (Pochodovat!), jejíž titul byl převzat z rozkazu generála Edwarda Śmigłego-Rydze vydaného polskému vojsku, jež dostalo 1. 10. 1938 rozkaz vstoupit na české Těšínsko.

Snahu o objektivní zachycení života obyvatel Těšínska, byt s důrazem na problémy polské národnostní menšiny, sledujeme i v reportáži Ślask za Olza (1938) z pera potomka českobratrských emigrantů v Polsku Pawła Hulki-Laskowského (1881-1946). Kniha vznikla v letech 1936-1937 na základě autorovy cesty po českém Těšínsku, včetně Karviné, a jeho pozorování průběžně konfrontovaných s dostupnou odbornou polskou i českou literaturou. Autor místy formuluje přiliš povrchní soudy, někdy nadmíru podléhá jednostranně zaměřené literatuře, ale v polsko-československém sporu konce třicátých let šlo o ojedinělý hlas zdravého rozumu. Polemiku vede - jak se dalo očekávat - se Slezskými pisněmi Petra Bezruče, které uznává $\mathrm{z}$ hlediska jejich básnické hodnoty a v nich obsaženého sociálního protestu, ale má výhrady vůči básníkovu pojetí národnostní problematiky. Podobně vede spor s pracemi Joži Vochaly. České Těšínsko se autor snažil představit jako místo, které by mohlo být mostem přátelství mezi oběma národy, zatímco se stalo ohniskem národnostních třenic.

Vedle těchto autorů menšího významu se objevuje i několik mladých talentů. V Ustroni vydaný almanach Szum Olzy (Šumění Olzy, 1932) obsahuje tvorbu Gustawa Przeczka, Adolfa Bujoka (redaktora př́ležitostného tisku), Czesława Sporysze. Do předválečného časopisu Ogniwo přispíval také folklorista a etnograf Józef Ondrusz.

9 Josef (Joža) Vochala, 1892-1965, národopisný a vlastivědný pracovník, publicista, organizátor spolkového dění, muzejník. Byl mj. autorem velmi sporných teorií o původu a povaze lašské kultury, jejíž kořeny hledal až na počátku slovanského osídlení. 


\section{Gustaw Morcinek - spisovatel, který uvedl slezskou tematiku do polské literatury}

Narodil se 25. 8. 1891 jako Augustyn Morcinek do chudé rodiny v Karviné. Byl nejmladším ze čtyř sourozenců. Jeho otec Józef zemřel v roce 1892 a matka Marie (roz. Smurówa) se musela starat o celou rodinu. Ve svých šestnácti letech začal pracovat v dole, když mu bylo devatenáct let, horníci udělali sbírku, aby se mohl vzdělávat. Morcinek začal navštěvovat učitelský seminář v Bělé (dnes Bílsko-Bělá, polsky Bielsko-Biała), který ukončil v roce 1914 a ve stejném roce byl povolán do rakousko-uherské armády. Po roce krátce sloužil 1918 i v polské armádě. V roce 1920, kdy bylo Těšínské Slezsko rozděleno mezi Polsko a Československo, přičemž jeho rodná Karviná zůstala na československé straně, rozhodl se zůstat v Polsku. Ve dvacátých a třicátých letech pracoval jako učitel v Skočově, zároveň se věnoval spisovatelské činnosti. Náležel k literární skupině Przedmieście (Předměstí). Během meziválečného období Morcinek publikoval množství článků v různých slezských peridikách. Svá nejdůležitější díla napsal ke konci dvacátých let a na začátku třicátých let a stal se nejznámějším prozaikem ze Slezska píšícím v polštině v meziválečném období. Jeho díla se zaměřovala především na hornickou tematiku a na slezská témata. Morcinek vystihl realisticky hornickou práci a život a zdůrazňoval sociální charakter národního útlaku polských horníků. Léta 1936-1939 strávil Morcinek částečně na cestách po západní Evropě.

Morcinek se vrátil do Polska krátce před vypuknutím druhé světové války. Dne 6. 9 . 1939 byl zatčen gestapem a zpočátku byl vězněn spolu s příslušníky pokrokové slezské inteligence. Nejprve byl internován ve sběrném táboře ve Skrochovicích u Opavy, pak po zbytek války v koncentračních táborech Sachsenhausen a Dachau. Předpokládaným důvodem jeho zatčení byla protiněmecká aktivita před válkou a skutečnost, že absolvoval propagační literární setkání pro Poláky ve Vestfálsku, že si dělal legraci z německého pěveckého kroužku Gesangvereinu ve fejetonu Cyrk w miasteczku (Cirkus v městečku) a že pes v jedné z jeho novel (Wyrabany chodnik) se jmenoval Bismarck. Během pobytu v koncentračních táborech dostal možnost podepsat Volkslistu, ${ }^{10}$ ale to odmítl.

Po osvobození žil Morcinek až do listopadu 1946 ve Francii, Itálii a Belgii, spolupracoval s polským emigračním tiskem v těchto zemích. Poté se vrátil do Polska a usadil se v Katovicích. Po svém návratu aktivně podporoval novou vládu, Polskou sjednocenou dělnickou stranu a znovu začal psát. V letech 1952-1957 byl poslancem Sejmu za volební obvod Katovice jako člen centristické strany Stronnictwo Demokratyczne (Demokratická strana).

Jako spisovatel se nadále se zabýval slezskými tématy, ale rozšíril své dílo o knihy pro děti a věnoval se epistolografii. Většina Morcinkových děl je věnována životu ve Slezsku, především práci horníků, soicálním a národnostním bojům proti germanizačnímu útlaku, protiněmeckým povstáním slezského lidu. Morcinek vytvořil model masové popu-

10 Deutsche Volksliste (listina Germánů či listina Němců), zkr. DVL, byla listina, která měla za cíl zařazení obyvatel na Němci dobytém území za druhé světové války do kategorií podle kritérií „vhodnosti“ sestaveným dle Heinricha Himmlera. Každý kdo byl veden v DVL, byl považován za Němce (a každý Němec měl jistá privilegia i povinnosti). 
lární četby, která si svou bezprostředností, bohatstvím reálií, příklonem k pracujícímu člověku, lidovým a folklorním tradicím, chválou přírody a lidské pospolitosti získávala čtenáře v celém Polsku. Řada těchto děl je věnována mládeži, beletristicky zpracoval vzpomínky na své karvinské mládí, příběhy z partyzánského odboje a koncentračních táborů. Čtenářský úspěch zaznamenaly slezské pohádky a vyprávění nebo romanticky pojatý román o slezském zbojníkovi Ondrášovi.

Gustaw Morcinek zemřel na leukemii 20. 12. 1963 v Krakově a je pohřben na obecním hřbitově v Těšíně (pol. Cmentarz Komunalny w Cieszynie). Během svého života obdržel řadu uznání a literárních cen za svou práci, jeho knihy byly přeloženy a publikovány v zahraničí. Po Morcinkovi byl pojmenován někdejší černouhelný důl v Kačicích (Polsko) na polsko-českém pomezí a ulice v Karviné.

Dosavadní recepce díla Gustawa Morcinka v Československu a v České republice je mizivá. Teprve po jeho smrti se s ním rozloučil publicista, překladatel a rozhlasový pracovník Milan Rusinský nekrologem v Červeném květu. „Gustaw Morcinek zajisté nepatřil $k$ oněm literárním tvưrcům, myslitelům, kteři svým dílem př́djimaji dobu. Byl však výmluvným vyprávěčem, jehož početné umělecké dílo patřilo $k$ nejčtenějším knihám v širokých lidových vrstvách."11 Rusinský se nevyhnul ani složité a citlivé otázce polsko-českých vztahů v díle slezského spisovatele, ale učinil tak diplomaticky: „Morcinkovo vyprávěčství prošlo vývojově velmi křivolakou dráhu, nežli se ideově zpevnilo a ustálilo. Mezi desítkami jeho knih najdeme několik, které nás musely i zabolet. Nicméně úporné překonáváni mnoha předsudků a mnoha tiživých pozůstatků v myšleni autorově, jež měly zdroj předevšim v jeho tiživém dětství, jež svět a jeho lidi poznávalo právě takové, o jakém později vypravoval, toto zdoláváni četných zábran bylo samo o sobě velkým, tvůrčím činem." 12 Autor nekrologu lituje, že ani z Morcinkovy novelistiky dosud nebylo do češtiny přeloženo nic, spisovatele přitom přirovnává $\mathrm{k}$ ostravskému Vojtěchu Martínkovi. „Ukázalo by nám, jakým vypravěčským talentem byl spisovatel, který se dovedl pozorně zahledět na lidi a predevším zaposlouchat do jejich hovorové mluvy, z niž vyvážil tolik překvapivé básnické metaforiky, gnómické moudrosti, kouzelných slovních obratů. A jakým dovedl být barvitým kronikárem zejména oněch devadesátých let, o něž se opírá převážná část Morcinkova dila, pripominajicího nám romány našeho ostravského Vojtěcha Martínka, s jehož př́stupem k látce má dílo jeho polského vrstevnika hodně společného. "13 V závěru článku Rusinský lituje, že se Morcinek již nepodívá znovu na svou „Černou Julku“, aby v ní byl spravedlivější k řadě postav, ani na svého „Ondráše“, aby ho obdařil více posláním buřiče než romantického reka. Rusinský také připomíná besedy se spisovatelem na Ostravsku a Karvinsku: „Poznávali jsme Gustawa Morcinka na Ostravsku nejen jako autora četných románů a svazků novel, ale i jako temperamentniho vyprávěče, který na četných čtenářských besedách i u nás na Ostravsku přmo před posluchači demonstroval své pohotové vyprávěčství, své svěži a barvité rozvíjeni motivů, tvořicich základ jeho besedováni. Zi̊stane nám dlouho i jako vyprávěč i jako tvůrce dlouho v paměti."14

11 RUSINSKÝ, Milan: Za vyprávěčem z polského Slezska. Červený květ, 1964, č. 2, s. 63.

12 Tamtéž.

13 Tamtéž.

14 Tamtéž. 
Později, v roce 1976, píše Rusinský v rozhlasovém příspěvku Spisovatel hornického svě$t a^{15}$ (nachází se v archivu pozůstalosti autora v Památníku petra Bezruče v Opavě, dále zkr. PPB), o „novém výboru“ z Morcinkova novelistického díla, který „právě“ vyšel v katovickém nakladatelství Śląsk na prahu nedožitých pětaosmdesátin spisovatele: „Je škoda, že nebylo z jeho velmi rozsáhlého románového a novelistického dila nic přeloženo do češtiny,"16 posteskl si autor příspěvku. „Přičiny toho byly různé, nejednou zavdal autor sám svým dávným někdejším postojem k českým věcem, jejž po válce a po svém návratu z šestiletého koncentráku energicky odmítl. Vždyt’ v nejhrůznĕjšich podminkách mu zachránili život vlastně čěstí spoluvězni. "17 Ze stejného roku pochází rozhlasový příspěvek Spisovatel, patř́ci lidu, kde se také nachází komparativní poznámka o blízkosti Morcinkova díla tvorbě ostravského spisovatele Vojtěcha Martínka. Morcinek se výslovně distancoval od svých dřívějších názorů na předválečné Československo, Rusinský o tom vydává svědectví v nedatovaném příspěvku bez názvu, ${ }^{18}$ uloženém v Památníku Petra Bezruče v Opavě.

V dalším (nedatovaném) rozhlasovém příspěvku ${ }^{19}$ nepochybně napsaném k výročí nedožitých devadesátin - tedy v roce 1981 - si Rusinský všímá soupisu knižně vydaných děl, který „dosahuje téměr jedné kopy. Přsněji - 59 názvi̊ různých knih. A to do tohoto úctyhodného dila nejsou započitány některé výbory povidek, obsahujici také práce z pozůstalosti autorovy. "20 Rusinský ke konci jubilejního textu opět považuje za škodu, „že aspoň z pozdějšího Morcinkova díla nebylo něco přeloženo do češtiny. Jeho veliký román Sloj Joanna, nebo jeho fejeton Z mé země, autobiograficky laděná Černá Julka, výbor z jeho hornických novel - to v̌sechno jsou díla, která by měla být v překladu přistupna i českému čtenáři, včetně rozkošného cyklu hornických povidek Sedm hodinek hrobnika Joachima Rybky." ${ }^{21}$ A na závěr si Rusinský posteskl: „Těch několik málo překladů z drobné prózy Morcinkovy, které byly u nás tu a tam časopisecky [publikovány], zdaleka nepodá obraz tak složitého tviorčího a vypravěčského zjevu literárního, jako je právě náš karvinský rodák a předni narrator polské současné prózy, Gustaw Morcinek. Vpravdě tvuirce hornického polského románu, který by mohl být svým přistupem k tématu vzorem $i$ našim autorům." 22

Alespoň slovenští čtenáři se mohli seznámit s překladem Morcinkova románu Czarna Julka v roce 1986 pod názvem Čierna Julka (Bratislava, Mladé letá) v překladu Růženy Jamrichové. Na Slovensku v Trnavě vyšel ještě v meziválečném období Morcinkův román Boli dvaja bratia (1936) v překladu Petra G. Skalanoviče, který v roce 1940 pro Spolok Svätého Vojtecha v Trnavě ještě přeložil Morcinkovu prózu Ludia sú dobrí.

Problém zřejmě spočíval v neochotě českých nakladatelství vydat cokoli knižně z Morcinkovy tvorby, přestože jim mohla být doporučována $\mathrm{k}$ vydání, jelikož vedení nakla-

\footnotetext{
15 PPB, fond 40A, př. č. L3/94/1426.

16 Tamtéž.

17 Tamtéž.

$18 \mathrm{PPB}$, fond 40A, př. č. L1/94/1944.

19 PPB, fond 40A, př. č. 55/73/5584.

20 Tamtéž.

21 Tamtéž.

22 Tamtéž.
} 
datelství mohlo mít v povědomí spisovatelovy předválečné postoje k Československu. ${ }^{23}$ Kladné (nedá se očekávat, že bezvýhradné) přijetí Morcinkova díla u nás zkomplikovala recenze Josefa Šinovského (vl. jm. Josef Bilan) románu Czarna Julka (Varšava, 1959) na stránkách Červeného květu ${ }^{24}$ : „Autor zde na stránkách celé knižky záměrně pomīji třídní vykresleni i dělnické revolučni hnutí [...]. Měl by právě zde vykreslit u každé národnostni skupiny nezaujatě tř́dni protivy tehdejši doby." 25

Ani Morcinkova poválečná sebekritika, na kterou upozorňoval Rusinský, nemusela převážit obavy z cenzurních zásahů po případném vydání některého titulu z Morcinkova obsáhlého díla. Avšak ani pro tuto hypotézu nemáme zatím přímé důkazy, jsou pouze doklady o tom, že pro české vydání Morcinkových literárních prací horoval Rusinský na vlnách Českého rozhlasu Ostrava.

A tak v českém prostředí došlo až po třiadvaceti letech od politických změn v roce 1989 alespoň k překladu a knižnímu vydání vybraných Morcinkových hornických pověstí v polštině a češtině (překladu do češtiny se ujal autor této statě) pod názvem $Z$ ř́še Pusteckého - Z krainy Pusteckiego (Český Těšín: Sdružení přátel polské knihy, 2012). V tomto edičním úsilí by bylo vhodné pokračovat v podobném duchu, jak se k potřebě uvést Morcinka alespoň částečně do české literatury před léty vyjadřoval Milan Rusinský.

\section{Básník a emigrant Adolf Fierla}

Adolf Fierla se narodil 16. 1. 1908 v Orlové do hornické rodiny, která zprvu žila v Bohumíně, pak se rodiče přestěhovali do Orlové. Vlastenecky cítící rodina patřila k zakladatelům Polského reálného gymnázia v Orlové (v roce 1909), zasloužila se také o vybudování internátu (tzv. „bursy“) pro studenty ze vzdálenějších oblastí. V Orlové absolvoval Fierla zmíněné gymnázium, jemuž se říkalo „na Obrokach“. Po maturitě vystudoval polonistiku v Krakově a slavistiku v Praze, po absolutoriu se vrátil na orlovské gymnázium, kde vyučoval polský jazyk a literaturu. Jeho literární dráhu přerušila válka. Po nezdařeném útěku na Západ se vrátil do Orlové, v roce 1940 byl zatčen, vězněn v koncentračním táboře Dachau, poté Mauthausen-Gusen. Z koncentračního tábora byl propuštěn a vrátil se na Těšínsko, kde pracoval jako dělník v Petřvaldu, než byl povolán do armády. Ve Francii se dostal do anglického zajetí a na Západě už zůstal. Ke konci války se přihlásil na Polské vojenské misi v Paříži, která ho přidělila ke Kulturnímu a tiskovému oddělení v Avignonu. Zmíněné oddělení vydávalo od roku 1940 Dziennik Żołnierza, který byl v roce 1944 sloučen s Dziennikiem Polskim, s nímž Fierla navázal spolupráci. Koncem roku 1945 mu byla nabídnuta profese učitele a jako polonista pracoval na gymnáziu a lyceu, která založil „2 Korpus Wojska Polskiego“ pro dobrovolnice, tedy pro dívky, které se na školu dostaly z různých prostředí: z polské armády, s níž absolvovaly pochod z Východu přes

23 Srov. článek v Českém deníku z 26. 7. 1936, kde se píše o „polském protičeském románu Wyrabany chodnik“. Stejně je román hodnocen např. v Lidových novinách z 15. 7. 1936 a podobně v novinách Našinec z 19. 9. 1933, kde se o Morcinkovi uvádí, že je „znám z doby plebiscitní jako horlivý protičeský exponent“.

24 Josef Šinovský, Zamlžené cesty spisovatele G. Morcinka, Červený květ, 1959, č. 12, s. 328.

$25 \mathrm{PPB}$, fond 40A, př. č. 55/73/5584. 
Palestinu do Evropy, z nucených prací v Německu nebo z koncentračních táborů. Škola byla založena v Porto San Giorno v Itálii. Absolventky školy oceňovaly A. Fierlu nejen jako výborného polonistu, ale vzpomínaly na něho i jako na básníka. Ke konci roku 1946 byl 2. sbor Polské armády evakuován do Velké Británie a spolu s ním i škola, která byla přenesena do tábora Foxley v hrabství Hareford. Tady Fierla pracoval až do uzavření školy v roce 1948. Na školu pro dobrovolnice pak vzpomínal ve třech článcích uveřejněných v periodikách Polska Walcząca - Żołnierz Polski na Obczyźnie (1947), Dziennik Polski a Dziennik Żołnierza (1948). Jako učitel pak působil v gymnáziích v Bottishamu u Cambridge, Stowell Parku a Fairfordu, kde mj. vyučoval francouzštinu. V r. 1958 pedagogickou činnost ukončil a věnoval se hlavně literatuře. V Anglii se také v roce 1959 oženil s Izabelou Herrmannovou, dcerou továrníka a obchodníka s kůžemi, která se po pobytu ve Varšavě a Žirardově vystěhovala do SRN. Adolf Fierla spolupracoval s polským tiskem v Itálii, Francii, Velké Británii a Kanadě. Kromě zmíněných periodik přispíval do Orła Białego (Londýn), Narodowca (pod pseud. Andrzej Jakubiec) a Głosu Polska - Gazety Polskiej (Kanada). Mimo to přispíval do časopisu Polské evangelické církve augsburského vyznání v zahraničí Poseł Ewangelicki - Evangelical Herald. V polovině padesátých let se Fierla pokusil navázat kontakty s polskými periodiky v Polské lidové republice. Adolf Fierla byl evangelíkem augsburského vyznání. Několik textů uveřejnil v evangelickém kalendáři Kalendarz Ewangelicki na rok 1967 i v katolickém periodiku Tygodnik Powszechny. Zásluhou své manželky a biskupa Andrzeje Wantuły posmrtně vyšla ve Varšavě sbírka Poezje religijne (1971). Podle Edmunda Rosnera a Ludwika Brożka byla na Fierlově poválečné tvorbě patrná větší vyzrálost a pečlivost, co se týče básnického řemesla. Jako autor odtržený od svého rodného podhoubí byl nucen více vycházet $\mathrm{z}$ univerzálních témat, zvláště náboženských. V poválečné próze, podobně jako jiný emigrant ze Slezska Paweł Łysek (1914-1978), se Fierla snažil navazovat i na těšínský folklor, lidové zvyky a obřady. Vrací se k regionálně zabarveným vyprávěním Dziwy na Siwięta Barbórkę, Wielkocztwartkowe uroki, Legenda o jednym drewnianym kościótku ad., v nichž navazuje na svou prózu z třicátých let. Píše také biblické př́iběhy, např. Maria z Magdali a Godzina taski petna, vánoční texty - Legenda o trzech królach. V ř́jnu 1966 navštívil Fierla Polsko, pobýval v Krakově, Katovicích, přijel do Těšína (do Českého Těšína již přijet nesměl) a na pozvání Władysława Oszeldy (1907-2005) se setkal se čtenáři v polském Národním domě, mezi nimiž nechyběl ani Henryk Jasiczek (1919-1976), který po něm převzal žezlo nejoblíbenějšího básníka regionu. Adolf Fierla zemřel v Londýně 13. 9. 1967, pochován byl ve Finchley.

Adolf Fierla debutoval sbírkou Przydrożne kwiaty (1928) ve Fryštátu, kde také vyšla prvotina Pawła Kubisze. Fierlova pražská studia a toulky po Čechách přinesly ovoce v podobě knihy Czeskie grody $i$ zamki, kterou dedikoval tehdejšímu československému prezidentu Edvardu Benešovi a ten ho pozval k setkání na Pražském hradě. Kromě souborů povídek a novel Hatdy (1930) a Kamień w polu, románu Ondraszek (1931) vydal sbírky básní Cienie i blaski (1930), Dziwy na gróniach (1932), Kopalnia stoneczna (1933), Kolędy beskidzkie (1935). Poému Silesiada uveřejnil na stránkách Naszego Ludu (1926).

V meziválečném období byl A. Fierla nepochybně nejpopulárnějším polským básníkem českého Těšínska, autorem plodným a známým i za hranicemi regionu. Pět básnických sbírek, tři prozaické knihy a velké množství příspěvků v tisku (hlavně slezském) 
napovídá, že mu ze slezských spisovatelů nemohl plodností nikdo konkurovat s výjimkou Gustawa Morcinka. Rychle se rozrůstající literární dílo mělo za následek, že byl po určitou dobu bez větších protestů uznáván za jednu z hlavních osobností literárního života v Těšínském Slezsku. Svou autoritou ho dokonce podpořil Roman Dyboski, který napsal úvod k Fierlově sbírce Dziwy na gróniach, v němž autora označil za „pierwszorzędnego regionalnego poetę śląskiego“. Bez významu nebylo ani to, že sbírku Kopalnia stoneczna vydala krakovská Gazeta Literacka a tento fakt mohl na čtenáře i kritiku působit silným dojmem. Za svou uspíšsenou literární kariéru A. Fierla vděčil také tomu, že pocházel z českého Těšínska, což mu na polské straně zjednávalo oficiální podporu.

Fierla (člen Śląskiego Związku Literacko-Artystycznego ${ }^{26}$ ) přeložil sbírku Jiřího Wolkera (Wiersze wybrane, Praha, 1934), napsal o něm popularizující stat'Jerzy Wolker i jego dzieto (1933) a v roce 1938, bez ohledu na zostření politické situace mezi Československem a Polskem, vycházel ve Fierlově překladu v katovickém časopise Polonia na pokračování román Vojtěcha Martínka (1887-1960) Černá země. Fierlovy překladatelské snahy se však nesetkaly s pozitivním ohlasem polské kritiky, nikoli z důvodů estetických, ale jiných, např. na stránkách národovecky orientovaného katovického měsíčníku Kuźnica.

Fierla se v meziválečném období inspiroval výhradně regionem českého Těšínska a udržoval kontakty s některými českými spisovateli v oblasti, kromě ostravského Vojtěcha Martínka zaujmou jeho vztahy s českým kritikem Janem Strakošem (1899-1966), jenž měl uvádět recitační večer z poezie Fierly, Pawła Kubisze a Óndry Łysohorského (vl. jm. Ervín Goj, ${ }^{27}$ 1905-1989) v roce 1937 ve Frýdku, tedy v době, kdy na mezinárodní politické scéně došlo ke zhoršení vztahů mezi Československem a Polskem.

Strakoš kvůli Fierlově neochotě podílet se na společném recitačním večeru na básníka nezanevřel, kritik již dříve napsal recenzi na sbírku Dziwy na gróniach ve svém časopise Poesie (roč. 2, č. 3-4), na jehož stránkách propagoval tzv. čistou poezii pod vlivem francouzského básníka Henri Bremonda (1865-1933), ale také uváděl soudobou polskou poezii (E. Zegadłowicze, K. Iłłakowiczównu). ${ }^{28}$ Po večeru byl vydán „almanach slezského písemnictví krásného“ Náš hlas (Frýdek, 1935) a Strakoš jako jeho redaktor v něm umístil Fierlovu báseň Černý kraj v překladu Jaroslava Závady.

Celý Fierlův svět byl uzavřen do prostoru karvinského hornického revíru a zemědělské oblasti, která k němu přiléhala z východu, a slezských Beskyd. Jako básník dokázal zobrazit úzký okruh námětů - horníka a důl, sedláka a jeho práci, beskydskou krajinu a horalský folklor. Osobní prožitek v jeho básnické tvorbě nesehrává téměř žádnou úlohu, vůbec v ní nenajdeme intimní lyriku; byl u něho nahrazen literární stylizací a manýrou, svět jeho básní je mrtvý a prázdný.

Ve sbírkách Dziwy na gróniach a Kolędy beskidzkie (v tomto případě je již titul téměř úplným plagiátem Zegadłowiczovy sbírky Kolędziotki beskidzkie, 1923) najdeme několik krátkých, lyricky zabarvených popisů, občas stylizovaných podle vzoru lidové písně.

26 Slezský literárně-umělecký svaz; ŚZLA, vznikl v roce 1937.

27 Setkáváme se i s variantou Erwin Goy.

28 ŠAJTAR, Drahomír: Básnik Adolf Fierla a kritik Jan Strakoš. In: Literatura v českém a polském Slezsku Literatura na Śląsku czeskim i polskim. Ed. Libor Martinek. Opava - Cieszyn: Slezská univerzita - Filia UŚ, 1996, s. 72. 
K zdařilejším patř́ gavendy ${ }^{29}$ se stylizací lidové epiky $Z$ putynki a Satajka. Třetí z těchto dílek Chachar je téměř úplným plagiátem Kubiszovy básně $W$ putyce, ${ }^{30}$ otištěné v časopise Zaranie Śląskie, posléze zařazené do sbírky Przednówek. Hierowski v závěru svých poznámek tvrdí, že celá Fierlova beskydsko-náboženská lyrika nepřináší žádnou literární hodnotu. Podle autora Życia literackiego na Ślasku w latach 1922-1939 (Katovice, 1969) básnická tvorba Adolfa Fierly reprezentuje těšínský regionalismus v jeho nejhorší podobě. Odhaluje všechny slepé uličky, nepřirozenosti, falšování, k nimž vedlo zjednodušené a povrchní provozování literárního regionalismu.

Daleko laskavější byla k Fierlovi dobová česká kritika. J. Strakoš srovnával v recenzi sbírky Dziwy na gróniach jeho poezii s českými básníky Petrem Bezručem a Jiřím Wolkerem: „Fierla je lyričtějši obou našich sociálních básniků. Sociálni patos je u něho ztlumen právě tím básnickým úchvatem z krajinného živlu i hudby práce. Fierla zpivá tam, kde Bezruč a Wolker spřádaji osnovu sociálniho programu... Fierla je především básnik, jenž hudebním instinktem dobývá svého tvaru básnického. [...] Kristus tu procházi jako tajemný vládce vuši té nádhery přírodni. [...] Poláci jsou o tolik štastnějš́ nás, že dovedou krajový folklor promítnout do pozadi skutečné básnické tvorby - Zegadtowicz a Fierla nám scházeji.“"31

Přesto se Fierlova tvorba dnes jeví jako z převážné části epigonská, myšlenkově plytká a umělecky slabá.

\section{Jerzy Stanisław Polaczek - amicis Bohemiae}

Literárního života českého Těšínska se aktivně účastnil také spisovatel Jerzy Stanisław Polaczek, rodák z Chabówky (3. 11. 1905). Pocházel ze železničářské rodiny, později se rodina přestěhovala do Krakova, kde J. S. Polaczek vystudoval a kde byl zaměstnán v Ústředních dílnách železničního vojska (Centralny Warsztat Wojsk Kolejowych). Posléze se stal novinářem, působil v Głosu Naroda (Hlasu národa) a přispíval do literárních časopisů (mj. Gazeta Literacka, Kurier Literacko-Naukowy, Kurier Kobiecy, Pittsburczanin, Tempo Dnia, po válce mj. Poglądy). Ve třicátých letech a pak v šedesátých až sedmdesátých letech 20. století se zapojoval do polského menšinového literárního života $\mathrm{v}$ Československu. Jeho manželka Waleria Krajičková pocházela z polské rodiny v Dombrové (Doubravě, okr. Karviná), kde žil s rodinou až do začátku války. Před válkou působil v Mezinárodním sdružení novinářů v Praze a jako tiskový referent na polských konzulátech v Praze, Bratislavě a v Ostravě. V Praze vystudoval politologii. Byl šéfredaktorem Dziennika Polskiego (Polského deníku), aktivně působil v ŚZLA a patřil k jeho zakladatelům. Za války žil v Krakově, kde pracoval na ředitelství Městských vodovodů

29 Srov. gawęda - gavenda. In: ŠTĚPÁN, Ludvík a kol.: Slovnik polských spisovatelů. Praha: Libri, 2000, s. 156. (Autorkou hesla je Krystyna Kardyni-Pelikánová.)

30 Obě básně srovnává Władysław Sikora ve stati Chachar dwóch autorów v knize esejů Wielokropki (Katovice: Śląsk, 1982). Básně mají stejné téma, ale interpretace se jeví odlišná. Sikora srovnává jednotlivé pasáže obou autorů, rozebírá užití jazykových prostředků, které díla použivají (v tomto případě nářečí). Z celého srovnávání vyplývá, že Kubisz pracoval s nářečím velmi dobře na rozdíl od Fierly, jenž nedovedl využít jeho funkce.

31 ŠAJTAR, Drahomír: Op. cit., s. 74. 
a kanalizací. Po válce byl korespondentem Polského rozhlasu a ředitelem Polské tiskové agentury (Polska Agencja Prasowa) v Praze. Byl však prohlášen za nepř́itele komunismu, po dobu svého působení v Praze byl sledován a na základě falešného obvinění odvolán ze všech funkcí. V Krakově byl souzen a hrozil mu trest smrti. Vězení si odpykal v táborech nucených prací v Sztumě a Opolských Střelcích. V roce 1955 mu byl zbytek trestu prominut. Ke své novinářské profesi se vrátil až v roce 1966 v Głosu Ziemi Cieszyńskiej (Hlasu těšínské země), kde do roku 1970 zastával funkci redaktora a šéfredaktora. Zemřel 18. 2. 1982 v Českém Těšíně, pochován je v Dombrové (Doubravě).

Jako básník tvořil J. S. Polaczek pod vlivem polské avantgardy, zejm. Juliana Przybośe a Juliana Tuwima, ze současníků se přátelil s Jalu Kurkem (1904-1983). Náměty ke své tvorbě čerpal ze sportovního prostředí (pod vlivem Kazimierze Wierzyńského, autora známé sbírky Laur olimpijski /Olympijský věnec/, 1928), jak o tom svědčí v Československu vydané sbírky poezie: Pochód olimpyjczyków (Pochod olympioniků, 1931), Algebra zwycięstwa (Algebra vítězství, 1932) a Witraż Celzjusza (Celsiova vitráž, 1936), která získala uznání recenzentů.

J. S. Polaczek se inspiroval i hornickým prostředím, jak o tom vypovídají jeho časopisecky uveřejňované povídky a novely, případně práce z pozůstalosti (strojopisný román Cztowiek $z$ S w. Trójcy /Člověk od sv. Trojice/). Vladimír Keppert přeložil do češtiny jeho román z prostředí železnice Żelazny Bóg (Kraków, 1933) - Železný Bůh (Moravská orlice, 1934). J. S. Polaczek obdržel český Řád bílého lva v důstojnické hodnosti za zásluhy na poli sblížení obou národů.

\section{Shrnutí}

Jak vyplynulo dostatečně průkazně z výše komunikovaného, regionální literatura Karvinska se rozvíjela díky několika osobnostem, zejména písíím v polském jazyce, kteří Karvinsko uvedli do polské literatury v regionu, ale i v Polsku. Čeští spisovatelé (vyjma Petra Bezruče), kteří si z regionu brali inspiraci, se nemohli významem svého díla rovnat umělecké úrovni polské tvorby Gustawa Morcinka, Adolfa Fierly nebo Jerzyho Stanisława Polaczka.

\section{Literatura}

BEZRUČ, Petr: Slezské pisně. Ed. Drahomír Šajtar. Praha: SPN, 1958.

MARTINEK, Libor: Region, regionalismus a regionálni literatura. Opava: Slezská univerzita, 2007.

MARTINEK, Libor: Życie literackie na Zaolziu 1920-1989. Kielce: Oficyna wydawnicza „STON2“, 2008.

MARTINEK, Libor: Ke kritickému obrazu české literatury na stránkách časopisu Weles. In: Obraz české a slovenské literatury v literární kritice. Opava: Slezská univerzita, 2010, s. 9-21.

MARTINEK, Libor: Multietnická literárni kavárna AVION v Českém Těšině existuje na styku kultur. XLinguae. A Trimestral European Scientific Language Review (Nitra), 2010, č. 1, s. 14-22. 
MARTINEK, Libor: Identita v literatuře Těšinska. Opava - Kielce: Literature \& Sciences - Oficyna wydawnicza „STON2“, 2015.

MARTINEK, Libor: Milan Rusinský o Gustawu Morcinkovi. Časopis Slezského muzea. Série B - vědy historické 59, 2010, č. 1, s. 79-87.

MARTINEK, Libor: Jerzy Stanistaw Polaczek - Amicus Bohemiae. Těšínsko, 2011, č. 2, s. 15-17.

MARTINEK, Libor: Básnik a emigrant Adolf Fierla. K problematice česko-polských literárnich vztahi̊ na českém Těśinsku v meziválečném obdobi. Těšínsko, 2012, č. 2, s. 18-24.

MARTINEK, Libor: Problematika krytycznej recepcji twórczości Wiestawa Adama Bergera. Zwrot, nr 11, s. $45-47$; nr 12 , s. $44-46$.

MARTINEK, Libor: Pawet Hulka-Laskowski - stavitel mosti̊ mezi národy. Slavica litteraria 20, 2017, č. 1, s. 39-60.

RUSINSKÝ, Milan: Za vyprávěčem z polského Slezska. Červený květ, 1964, č. 2, s. 63.

RUSINSKÝ, Milan, osobní fond autora, Památník Petra Bezruče v Opavě, fond 40 A.

ŠAJTAR, Drahomír: Básnik Adolf Fierla a kritik Jan Strakoš. In: Literatura v českém a polském Slezsku - Literatura na Śląsku czeskim i polskim. Ed. Libor Martinek. Opava - Cieszyn: Slezská univerzita - Filia UŚ, 1996, s. 69-75.

ŠINOVSKÝ, Josef: Zamlžené cesty spisovatele G. Morcinka. Červený květ, 1959, č. 12, s. 328.

ŠTĚPÁN, Ludvík a kol.: Slovnik polských spisovateli̊. Praha: Libri, 2000.

doc. PhDr. Libor Martinek, Ph.D.

Ústav bohemistiky a knihovnictví

Slezská univerzita v Opavě

Masarykova tř. 37, $746010 p a v a$, Česká republika

martinek.libor@centrum.cz

Instytut Filologii Słowiańskiej

Uniwersytet Wrocławski

Pocztowa 9, 53-313 Wrocław, Polska

libor.martinek@uwr.edu.pl 